\author{
Jacek Strojny \\ Politechnika Rzeszowska \\ im. Ignacego Łukasiewicza
}

\title{
Analiza potencjału przedsiębiorczego województwa podkarpackiego
}

Rozwój systemów gospodarczych jest jednym z bardziej popularnych i interesujących zagadnień w naukach społecznych. Nie dziwi zatem fakt, że naukowcy reprezentujący różnorodne dyscypliny naukowe: socjologię, ekonomię, organizację i zarządzanie, nauki prawne i wiele innych próbują tworzyć własną przestrzeń badawczą. Jednocześnie należy zauważyć, że większość problemów, na jakie napotykają procesy rozwojowe, ma charakter interdyscyplinarny, a przez to ich wyjaśnienie wymaga spojrzenia szerszego niż z perspektywy jednej dyscypliny naukowej. Taki stan rzeczy tworzy przestrzeń do holistycznej analizy rzeczywistości i włączania się w dyskurs na temat danego problemu przedstawicieli innych, często wydawałoby się tematycznie odległych dyscyplin. Mimo zagrożeń w postaci zbytniego chaosu i często wręcz nadprodukcji definicji pojęciowych, tego typu sytuacja sprzyja rozwojowi nauki jako całości i stanowi pożywkę dla nowatorskich teorii oraz rozwoju w obszarze rzeczywistości społeczno gospodarczej. Przedstawiona sytuacja dotyczy oczywiście również tematu rozwijanego w ramach niniejszego opracowania. Analiza potencjału przedsiębiorczego regionu wymaga bowiem zrozumienia wielu procesów zachodzących w różnych wymiarach, ale wzajemnie się determinujących, a więc tworzących rozbudowaną sieć relacji przyczynowo-skutkowych, których efektem jest określony poziom zdolności do rozwoju.

\section{Model analizy przedsiębiorczości w kontekście rozwoju systemu gospodarczego}

Jednym z zadań, jakie postawił przed sobą autor niniejszego artykułu, jest właśnie identyfikacja podstawowych zewnętrznych i wewnętrznych wymiarów determinujących rozwój regionu. Ze szczególną uwagą analizie poddany zostanie zbiór determinant określanych jako potencjał przedsiębiorczy. W celu dokonania możliwie pełnego (na miarę skromnych rozmiarów niniejszej publikacji) opisu mechanizmu przenoszenia się potencjału przedsiębiorczego na procesy rozwojowe przyjęty został schemat analizy obejmujący kilka podstawowych elementów. Autor postara się wyjaśnić proponowaną przez siebie koncepcję mechanizmu kształtowania się potencjału przedsiębiorczego na czterech podstawowych poziomach: 1) indywidualnym (pojedynczego człowieka), 2) społecznym (grup społecznych, społeczności), 3) organizacyjnym (zasad i mechanizmów współpracy w ramach organizacji) oraz 4) gospodarki (systemu gospodarczego). Tworzą one wewnętrzny kontekst kształtowania się potencjału przedsiębiorczego, decydując o jego poziomie w systemie gospodarczym (wyodrębnionym zarówno na szczeblu JST, jak i krajowym).

Wszystkie z wymienionych wyżej wymiarów są specyficzne dla każdego systemu gospodarczego, niezależnie od tego, na jakim poziomie jest on wyodrębniony. Czynniki determinujące przedsiębiorczość mogą natomiast być charakterystyczne wyłącznie dla danego 
terytorium albo mieć charakter uniwersalny - mogą np. oddziaływać jednakowo na wszystkie systemy. Dla przykładu można wyodrębnić czynnik w postaci nowoczesnych metod zarządzania, który wpływa na funkcjonowanie organizacji (determinuje ich rozwój), niezależnie od tego, gdzie są zlokalizowane. Również wymiar gospodarki kształtowany jest w dużej mierze na poziomie krajowym i w tym sensie charakteryzuje wszystkie jednostki terytorialne niższego szczebla. Wszystko to powoduje, że istnieją różnice potencjału przedsiębiorczego np. pomiędzy regionami czy jednostkami terytorialnymi na poziomie lokalnym. Wynikają one po pierwsze $\mathrm{z}$ kształtowania własnych regulacji lokalnych i w regionach odpowiednio przez władze lokalne (gminne i powiatowe) i regionalne. Ponadto poszczególne terytoria mają zróżnicowane warunki kształtowania się przedsiębiorczości (np. potencjał naturalny, społeczny, antropologiczny, a nawet uwarunkowania historyczne). Z drugiej strony jednak można zauważyć pewne podobieństwa, np. wzrost udziału usług w PKB, zmniejszanie się zatrudnienia w rolnictwie czy profesjonalizacja postaw pracowników. Wynikają one z oddziaływania na przedsiębiorczość czynników często z poziomu globalnego, a przynajmniej krajowego.

Dla pełnego odzwierciedlenia i oceny procesów wewnętrznych należy uwzględnić również zewnętrzny kontekst potencjału przedsiębiorczego. Można tutaj uwzględnić przynajmniej dwa procesy wiodące i mające duże znaczenie dla przedsiębiorczości oraz tempa rozwoju systemów gospodarczych, a więc globalizację i integrację europejską. Traktować je należy po pierwsze jako sferę benchmarkingu, która pozwala na odniesienie zmian zachodzących wewnątrz systemu do zmian obserwowanych w innych systemach gospodarczych, wybranych jako punkty odniesienia. Dzięki takiemu porównaniu możliwe jest określenie pozycji konkurencyjnej danego systemu gospodarczego. Po drugie, kontekst zewnętrzny jest też swego rodzaju rynkiem dla kapitału mobilnego, który, lokalizując się na określonym terytorium, wspiera wewnętrzne procesy rozwojowe, podnosząc potencjał przedsiębiorczy danego systemu gospodarczego. Schemat opisanej wyżej analizy przedstawia ryc. 1.

Ryc. 1. Wymiary przedsiębiorczości w kontekście rozwoju regionu

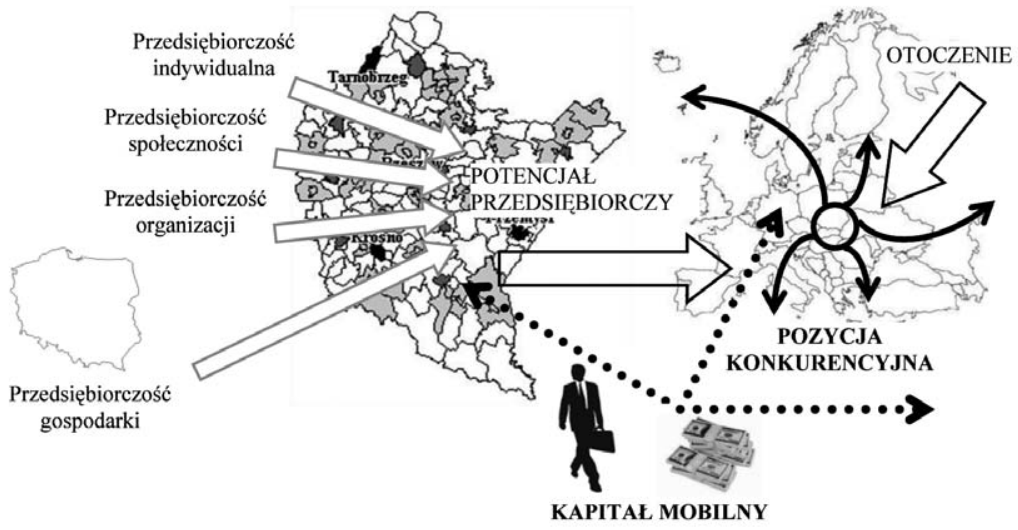

Źródło: opracowanie własne.

Konstruując zarysowany wyżej model analizy, autor artykułu zwraca uwagę, iż powinien on w jak największym stopniu odpowiadać na realne potrzeby podmiotów odpowiedzialnych za zarządzanie systemem gospodarczym. Jest to szczególnie istotne w przypadku kreowania strategii dla terenów, które mają wyraźne problemy rozwojowe. Dlatego też do zobrazowania prezentowanego tutaj podejścia wybrano jeden z najmniej rozwiniętych regionów Polski - 
województwo podkarpackie. Na jego przykładzie przeprowadzono ocenę wybranych wskaźników świadczących o poziomie potencjału przedsiębiorczego, analizowanego na poziomie gospodarki regionu. Przeniesienie proponowanego modelu na rzeczywistość społeczno-gospodarczą Podkarpacia ma za zadanie pokazać, iż może to być użyteczne narzędzie w procesach zarządzania strategicznego rozwojem regionalnym. Ponadto daje szansę określenia pozycji konkurencyjnej analizowanego województwa na tle np. innych województw Polski. Jest to możliwe dzięki analizie kontekstu wewnętrznego, przy uwzględnieniu oddziaływania procesów zewnętrznych, a więc integracji i globalizacji. Otwierają one z całą pewnością nową sferę konkurowania - konkurencję pomiędzy terytoriami o kapitał mobilny. Jest to relatywnie nowa sytuacja dla władz publicznych wymagająca od nich przyjęcia nieco innej perspektywy patrzenia na podmioty gospodarcze i obywateli. W miejsce podejścia administracyjnego musi pojawić się klientocentryzm i gotowość do rywalizacji z innymi podmiotami o to, aby zatrzymać istniejący oraz przyciagnąć z zewnątrz zarówno kapitał finansowy, jak i ludzki.

\section{Zlożoność procesu ksztaltowania się zjawiska przedsiębiorczości - ujęcie wielowymiarowe w kontekście rozwoju regionu}

Zjawisko przedsiębiorczości jest traktowane jako swego rodzaju czynnik sprawczy zmian rozwojowych na wielu różnych płaszczyznach. Pisze się o przedsiębiorczości indywidualnej, która wpływa na odniesienie sukcesu przez ludzi zajmujących się nie tylko działalnością gospodarczą, ale również wykonujących inne profesje. Rozumiana jest więc raczej jako cecha kardynalna niezbędna do elastycznego, rzutkiego i twórczego funkcjonowania w niemal każdej sferze aktywności człowieka. Przedsiębiorczość pojawia się też w wymiarze społecznym, a więc specyficznych cech kultury wyodrębnianej na różnych poziomach - od grupy społecznej po kulturę globalną. Wymiary kulturowy i indywidualny przekładają się również na sposób zarządzania organizacjami funkcjonującymi w danym systemie gospodarczym. Widoczne jest to w przyjętych strategiach rozwojowych, nastawieniu na inwestycje i innowacje oraz w budowaniu relacji wewnętrznych oraz zewnętrznych z innymi podmiotami. Przedsiębiorczość organizacji nie dotyczy oczywiście wyłącznie sfery produkcji (przedsiębiorstw). Powinna charakteryzować również instytucje publiczne czy organizacje non-profit. Całość analizy dopełnia wymiar przedsiębiorczości wyodrębniony na poziomie gospodarki. Jest ona kształtowana nie tylko przez władze regionalne i lokalne, ale w dużej mierze przez rząd, a w coraz większym stopniu także przez organizacje międzynarodowe (np. Unia Europejska). Na poziomie krajowym (makroekonomicznym) należy brać pod uwagę regulacje prawne.

Istnieje szereg procesów wiążących wymienione wymiary przedsiębiorczości i powodujących albo jej akcelerację albo, w niektórych wypadkach, wręcz przeciwnie - tłumienie. Wszystkie wymiary z pewnością stanowią razem nierozerwalną całość, którą traktować można jako mechanizm kreowania potencjału przedsiębiorczego, a więc swoisty i złożony system przedsiębiorczości. Bariery powstające na którymkolwiek z wymienionych poziomów analizy (wymiarów przedsiębiorczości) mogą skutecznie zahamować procesy rozwojowe całego systemu gospodarczego - gminy, powiatu, regionu, kraju, a nawet organizacji międzynarodowej, takiej jak np. Unia Europejska. Tymczasem właściwe oddziaływanie na poszczególne wymiary systemu przedsiębiorczości może doprowadzić do intensyfikacji procesów rozwojowych dzięki stworzeniu mechanizmów przekształcania niepewności w szanse. W ten sposób bezpośrednim efektem, który może zostać osiągnięty zarówno przez człowieka, jak i grupy społeczne różnej wielkości oraz organizacje, jest sukces. Rozumieć go należy jako stworzenie wartości dodanej, stanu jakościowo lepszego niż poprzedni, stanowiącego podstawowy efekt przedsiębiorczego działania. 
Ryc. 2. System przedsiębiorczości

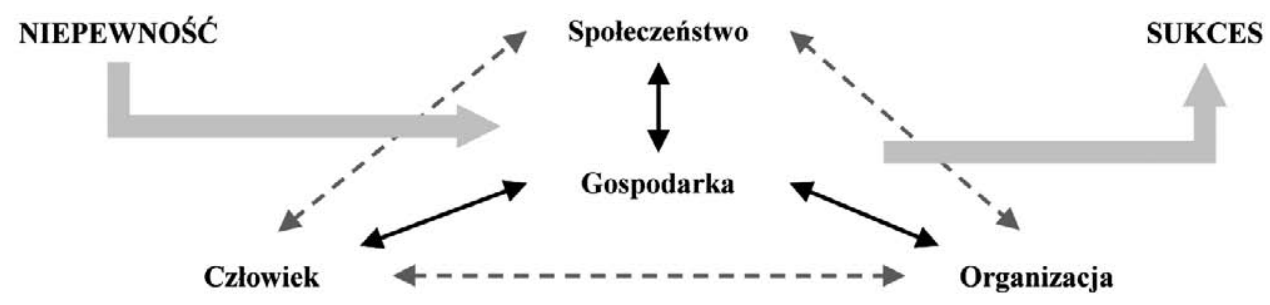

Źródło: opracowanie własne.

Zrozumienie budowy określonego wyżej modelu relacji pomiędzy wymiarami przedsiębiorczości wymaga skupienia się na dwóch podstawowych kwestiach. Po pierwsze należy określić, czym charakteryzuje się zjawisko przedsiębiorczości - za pomocą jakich określeń można je opisać. Następnie warto skupić się na poszczególnych wymiarach, opisując niektóre przynajmniej procesy determinujące poziom potencjału przedsiębiorczego. Ich określenie powinno stanowić wskazówkę dla instytucji odpowiedzialnych za rozwój systemów gospodarczych, na co zwrócić uwagę, realizując politykę społeczną i gospodarczą. Z tego samego powodu należałoby określić, jak przebiega oddziaływanie wymiarów na siebie, a więc w jaki sposób pozytywne i negatywne procesy przenoszą się na poszczególne wymiary modelu, powodując proces akceleracji bądź hamowania przedsiębiorczości, a co za tym idzie - również procesów rozwojowych w skali całego systemu gospodarczego.

Przedsiębiorczość jest pojęciem bardzo pojemnym oraz bardzo chętnie wplatanym w opis rzeczywistości w ramach różnych dyscyplin naukowych. W związku z tym istnieje bogactwo definicji ukazujących różnorodne, istotne dla danego problemu badawczego aspekty tego zjawiska. Przedsiębiorczość można bardzo ogólnie traktować jako zbiór atrybutów osoby, grupy, organizacji, systemu gospodarczego, który pozwala na dynamiczną reakcję na zjawiska zewnętrzne i wewnętrzne oraz na osiagnięcie sukcesu w postaci przejścia na wyższy poziom rozwoju (Strojny, Berezowska 2007). Przyjęcie takiej definicji sugeruje dwie podstawowe cechy przedsiębiorczości. Po pierwsze, jest to zjawisko poddające się opisowi za pomocą mierników skonstruowanych w odniesieniu do poszczególnych atrybutów. Specyfika mierników oraz metodologia pomiaru zależy od tego, jaki wymiar przedsiębiorczości bierze się pod uwagę. Inaczej zatem będą mierzone cechy osobowości przedsiębiorczej czy społeczności, a inaczej - przedsiębiorczość organizacji. Różny od wymienionych będzie również proces badania potencjału przedsiębiorczości w skali gospodarki. Druga cecha przedsiębiorczości, na którą należy zwrócić uwagę, to jej efekt w postaci odpowiednio zdefiniowanego sukcesu. Polega ona na skutecznym i efektywnym zrealizowaniu wizji, uzyskaniu wartości dodanej, a przez to osiagnięciu progresu w stosunku do stanu wyjściowego.

Przedsiębiorczość w swojej naturze to zjawisko determinujące aktywność prorozwojową, jest zatem przeciwieństwem stagnacji i biernego poddawania się oddziaływaniu czynników zewnętrznych. Ludzie o cechach przedsiębiorczych skłonni są do aktywnych postaw wobec problemów życiowych i zawodowych, przed którymi stają. Osoby takie mają poczucie własnego wpływu na rzeczywistość i starają się wykorzystywać nadarzające okazje do tego, żeby się rozwijać oraz aby powodować rozwój organizacji, w których uczestniczą. Podobnie grupy społeczne i społeczności zamieszkujące dane terytoria również wykazują aktywną postawę wobec problemów, jeśli cechuje je przedsiębiorczość. Kultura wytworzona w takim otoczeniu społecznym sprzyja zawiązywaniu relacji, zaufaniu, komunikacji i braniu odpowiedzialności. 
Całe społeczeństwa mogą być rzutkie i nastawione na rozwój przy jednoczesnym zrozumieniu konieczności ponoszenia ryzyka i kosztów w postaci wytężonego wysiłku. Organizacje charakteryzujące się potencjałem przedsiębiorczym są z kolei zdolne do eksperymentowania, wdrażania ambitnych programów rozwojowych i nastawione na elastyczną reakcję na wyzwania otoczenia konkurencyjnego i makrootoczenia. Dzięki temu mogą odnotowywać postęp, zwiększając obroty, wypracowując zyski i zaspokajając potrzeby klientów, do których adresują swoją ofertę 1 .

Na poziomie najbardziej ogólnym - gospodarki - przedsiębiorczość wynikająca z braku systemowych (strukturalnych) barier aktywności doprowadza do stworzenia zdrowych relacji pomiędzy podmiotami wszystkich kategorii. Gospodarka powinna sprzyjać racjonalności postępowania i eliminować wszelkie obszary, w których dochodzi do marnotrawstwa jakiegokolwiek rodzaju kapitału (a nawet czasu). Dzięki temu możliwe jest stworzenie podstaw do rozwoju, a więc ciagłej poprawy funkcjonowania podmiotów zlokalizowanych na danym terytorium (obywateli, przedsiębiorstw, instytucji publicznych, organizacji pozarządowych, itd.). W każdym z wymienionych wymiarów uzyskanie postępu i osiągnięcie założonych celów traktować należy jako osiągnięcie sukcesu.

Wyodrębnienie proponowanych czterech wymiarów przedsiębiorczości pozwala zwrócić uwagę na aspekt praktyczny, polegający na dobraniu odpowiednich instrumentów kształtowania przedsiębiorczości. Dzięki zidentyfikowaniu powyższych wymiarów możliwe jest przyjęcie metody badania natężenia zjawiska i oceny skutków podejmowanych działań. Należy jednak uświadomić sobie, że wszystkie wymiary (społeczny, organizacji czy gospodarki) uzależnione są od pierwotnego wymiaru, a więc przedsiębiorczości indywidualnej. To właśnie człowiek, dzięki intelektowi, zdolnościom, a także poprzez swoje zachowania w grupie, kreację przyjmowanych ról, sposób myślenia i reakcji na problemy, tworzy podwaliny potencjału przedsiębiorczego. W kreowaniu polityki rozwojowej systemu gospodarczego należy zwracać uwagę właśnie na tą swoistą zależność przyczynowo-skutkową pomiędzy wymiarami. Skuteczność przyjętych strategii dotyczących wspierania przedsiębiorczości zostanie zweryfikowana ostatecznie właśnie na poziomie indywidualnym. Nawet najbardziej wyrafinowane i przemyślane programy nie przyniosą efektu, jeśli nie pojawi się wystarczający odzew ze strony ludzi, do których są one adresowane. Aby zrozumieć opisaną wyżej zależność, należy opisać specyfikę poszczególnych wymiarów i ich wzajemne oddziaływanie.

Przechodząc do pierwszego z proponowanych wymiarów, a więc przedsiębiorczości indywidualnej, należy zwrócić uwagę, że bazuje ona na postawach i zachowaniach ludzkich ukierunkowanych na wykorzystanie okazji, kreowanie wartości dodanej oraz wprowadzenie w życie rozwiązań innowacyjnych. Wszystkie te działania oznaczają konieczność akceptacji ryzyka, a raczej umiejętności podejmowania decyzji w sytuacjach niepewnych, niecodziennych, wymagających kreatywnej i elastycznej odpowiedzi. Wielu autorów uważa, że tego typu przymioty mają postać swoistych cech indywidualnych człowieka (np. Zaleśkiewicz 2004; Kożuch 2001; Bratnicki 2002) składających się na jego osobowość. Naukowcy z wielkim zapałem podejmują się identyfikacji tych cech, proponując określone klasyfikacje lub po prostu wymieniając je w sposób mniej lub bardziej usystematyzowany. Większość jest przekonana, że podstawowe cechy człowieka przedsiębiorczego wiążą się z pasją tworzenia, dyscypliną

\footnotetext{
${ }^{1}$ Pojęcia „klient” oraz „oferta” należy tutaj rozumieć szerzej niż tylko w kontekście aktywności gospodarczej. Według autora wymagania wobec wszystkich organizacji (w tym instytucji publicznych) wzrosły tak bardzo, że współcześnie każdy odbiorca usługi oferowanej przez organizację powinien być traktowany jako klient (przyp. aut.).
} 
w realizacji celów, zaradnością, aktywnością, systematycznością, inicjatywą własną oraz zdolnością elastycznego dostosowywania się do rzeczywistości społecznej i gospodarczej (Juchnowicz 2004). Autor proponuje nieco inny zbiór cech, a mianowicie wskazując, iż przedsiębiorczość indywidualna wymaga ponadprzeciętnych zdolności intelektualnych, nastawienia na sukces oraz poczucia wewnątrzsterowności (Strojny 2009). Zbadanie poziomu natężenia przedsiębiorczości indywidualnej danej osoby jest możliwe poprzez zastosowanie odpowiednich kwestionariuszy. Oczywiście badania przeprowadzone w szerszej skali na próbie losowej dają podstawę do określenia, jaki jest poziom przedsiębiorczości indywidualnej na danym terytorium.

Wskazane cechy indywidualne ujawniają się w określonym otoczeniu społecznym, oczywiście wraz z wielkim bogactwem procesów zachodzących pomiędzy jednostką a grupą, w której funkcjonuje, społecznością danego terytorium, zespołem pracowniczym, itd. Osoby wchodzące w skład danego kręgu kulturowego mają pewne cechy wspólne (Linton 2000), które widoczne są w postaci zachowań zgodnych ze wzorcami wykształconymi i przyswajanymi w wyniku ciągłych interakcji społecznych (Kłoskowska 1997). Kultura daje więc możliwość wykreowania się tzw. osobowości podstawowej (Sillamy 1998), która pozwala przypisać przedsiębiorczość zachowaniom charakterystycznym dla osób tworzących daną przestrzeń kulturową. W takim ujęciu przedsiębiorczość należy traktować jako swego rodzaju profil osobowościowy o dużym wpływie na sposób, w jaki ludzie odczytują rzeczywistość i reagują na zachodzące w niej procesy. Można zatem przyjąć proponowaną przez Allporta propozycję klasyfikacji cech (Siek 1986), nazywając przedsiębiorczość cechą kardynalną - determinująca zachowania ludzkie oraz wspólną - wyłaniającą się na poziomie osobowości podstawowej, a nie tylko osobowości indywidualnej.

Oczywiście istnieje szereg uwarunkowań wpływających na jakość kapitału ludzkiego, a przez to na poziom przedsiębiorczości indywidualnej. Można tutaj mówić np. o poziomie wykształcenia, skłonności do otwierania przedsiębiorstw, skłonności do migracji, a także chęci budowania społeczeństwa obywatelskiego (w tym uczestniczenia w organizacjach non-profit, udziału w głosowaniach, referendach itd.). Są to wybrane cechy, które można zidentyfikować na podstawie danych statystycznych na poziomie społeczeństwa. Dodatkowo w tej analizie można skorzystać z odpowiednio sformułowanego kwestionariusza, który prócz wymienionych wyżej cech powinien identyfikować natężenie atrybutów społeczności składających się na kapitał społeczny. Chodzi tutaj także o takie cechy kultury, jak otwarcie na komunikację, zaufanie itd.

Kapitał społeczny rozumiany tak, jak proponuje to F. Fukuyama, stwarza możliwość kreacji współpracy międzyludzkiej dla realizacji wspólnych celów (Fukuyama 1997). Jest to zjawisko istotne szczególnie dla rozwoju sektora MŚP. W niewielkich przedsiębiorstwach nie istnieją wszak reguły biurokratyczne, zapewniające odpowiedni sposób postępowania w postaci opisanych procedur oraz innych wytycznych zarówno na poziomie strategicznym, jak i operacyjnym. Wykorzystuje się tam natomiast bezpośrednie relacje, pozwalające wzbogacić proces komunikacji i budować podstawy zaufania i wsparcia. Dzięki takiej specyfice przedsiębiorca ma swobodę kreowania postaw i budowania kultury przedsiębiorczości, sprzyjającej szybkim zmianom w odpowiedzi na wyzwania rynkowe. Oczywiście, aby zaistniało takie przełożenie się przedsiębiorczości indywidualnej na przedsiębiorczość całej organizacji, sam musi charakteryzować się wysokim potencjałem przedsiębiorczym. Tę zależność pomiędzy cechami przedsiębiorcy oraz cechami prowadzonej przez niego organizacji autor określa transmisją przedsiębiorczości (Strojny 2009). 
Znacznie bardziej skomplikowany jest ten proces w przypadku podmiotów dużych. Wspomniany wyżej mechanizm transmisji przedsiębiorczości nie jest bowiem możliwy bez wykorzystania odpowiednich metod zarządzania oraz złożonych procesów kreowania kultury organizacyjnej. Możliwe jest oczywiście kreowanie w ten sposób swoistego podejścia do zarządzania, które można określić mianem zarządzania przedsiębiorczego. Umożliwia ono reagowanie na gwałtowne zmiany tak charakterystyczne dla współczesnego otoczenia (Targalski 1999). Pozwala również radzić sobie z rosnącym naciskiem na wdrażanie innowacyjnych rozwiązań oraz ukierunkować strategię na ciagłe poszukiwanie szans (Janik 2006). Procesy zarządzania przedsiębiorczego w organizacji (przedsiębiorczości organizacji) można pogrupować w trzech podstawowych wymiarach: 1) myślenia strategicznego, 2) kreowania innowacyjności oraz 3) budowania kultury współpracy wewnątrz organizacji oraz poza nią (Strojny 2008b). Sfery te podlegają pomiarowi i ocenie na podstawie odpowiednio skonstruowanego kwestionariusza. Pozwala on oszacować wartość potencjału przedsiębiorczego organizacji.

Efekty aktywności grup pojedynczych osób, grup społecznych oraz organizacji kumulują się w postaci kondycji gospodarki. Dzięki wyborom politycznym dokonywanym na drodze demokratycznej grupy społeczne podejmują decyzję o kierunkach rozwoju państwa oraz samorządów terytorialnych. Tworzy się w ten sposób jeden $\mathrm{z}$ obszarów określających relacje między podmiotami w systemie gospodarczym, a mianowicie system instytucjonalno-polityczny. Ważne jest określenie, na ile pozwala on osiągnąć założone cele i reagować na zmiany w otoczeniu, a więc czy posiada atrybuty gospodarki przedsiębiorczej. Im bardziej system publiczny nastawiony jest na kreowanie zasad wolnorynkowych oraz ograniczanie wpływu administracji publicznej, tym ta sfera ma charakter bardziej przedsiębiorczy. Oczywiście zastanawiając się nad sferą wskaźników (atrybutów) świadczących o przedsiębiorczości, można wskazywać na: poziom obciążeń podatkowych, zakres swobody gospodarczej, nastawienie państwa wobec przedsiębiorstw i obywateli. Kolejna sfera, w której można identyfikować atrybuty przedsiębiorczości na poziomie gospodarki, to jej struktura. Chodzi tutaj zarówno o udział sfery publicznej w produkcji, jak i strukturę sektorową, a nawet strukturę wydatków.

Prezentowana, wielowymiarowa analiza przedsiębiorczości systemu gospodarczego wymaga oczywiście bardzo złożonych badań w celu oszacowania rzeczywistego poziomu przedsiębiorczości. Przyjmując, że wyjaśnienie stanu oraz wykorzystanie instrumentów oddziaływania na przedsiębiorczość wymaga poznania specyfiki wszystkich czterech wymiarów, należałoby zastosować następujący schemat postępowania:

1. Ocena przeciętnego poziomu przedsiębiorczości indywidualnej - a więc określenie modalnej osobowości przedsiębiorczej $\mathrm{w}$ danym systemie gospodarczym. Wymagałoby to wykorzystania na próbie losowej np. Kwestionariusza Przedsiębiorczości Indywidualnej, który proponuje autor artykułu (Strojny 2009). Dzięki takim badaniom można określić, czy system gospodarczy posiada fundament przedsiębiorczości w postaci potencjału indywidualnego mieszkańców. Oczywiście, aby zastosować określony instrument, można w ramach systemu gospodarczego wybierać określone grupy, w których przeprowadzane jest badanie, np. młodzież, przedsiębiorców, samorządowców itd.

2. Ocena poziomu przedsiębiorczości społeczności danego systemu gospodarczego. Tej sfery nie należy utożsamiać z przedsiębiorczością indywidualną, ponieważ odnosi się do relacji a nie do osobowości. Można tutaj zastosować kwestionariusz pozwalający na identyfikację nasycenia relacji międzyludzkich kapitałem społecznym. Oczywiście wyniki powinny być reprezentatywne dla danego systemu gospodarczego, a więc powinny zostać uzyskane w wyniku badania próby losowej. Mogą one znacząco wzbogacać informacje pochodzące z danych statystycznych i dotyczących takich atrybutów, jak skłonność społeczeństwa do 
ryzyka mierzona np. współczynnikiem migracji, poziom kompetencji mierzony strukturą wykształcenia, postawy obywatelskie mierzone skłonnością do otwierania organizacji pozarządowych czy też udziałem w wyborach. Oczywiście ważna jest też skłonność do otwierania przedsiębiorstw.

3. Ocena poziomu przedsiębiorczości organizacji mierzona np. proponowanym przez autora Kwestionariuszem Przedsiębiorczości Organizacji (Strojny 2009). Dzięki zastosowaniu odpowiedniego narzędzia pomiarowego możliwe jest określenie potencjału przedsiębiorczego np. sektora MŚP lub wszystkich podmiotów gospodarczych czy np. podmiotów z kapitałem zagranicznym. Po odpowiedniej modyfikacji możliwe jest jego zastosowanie również w innych organizacjach niż przedsiębiorstwa. Należy tutaj podkreślić, że wsparcie przedsiębiorczości organizacji np. poprzez dotacje (jest to instrument, którym posługuje się sfera publiczna w Unii Europejskiej, wtłaczając pieniądze w postaci licznych programów) jest elementem interwencjonizmu, który może wpływać na przebieg procesów wolnorynkowych. O wiele bardziej skutecznym wydaje się np. inicjowanie związków pomiędzy podmiotami, budowanie platformy komunikacji i współpracy w ramach klastrów innowacyjnych, itd. Oczywiście wskazanie sektorów, w których można inicjować tego typu aktywność wymaga wcześniejszego określenia potencjału przedsiębiorczego. Jego wysoki poziom wyjściowy będzie podłożem do akceleracji przedsiębiorczości w danym sektorze.

4. Ocena poziomu przedsiębiorczości gospodarki wymaga po pierwsze głębokich studiów z zakresu prawno-ekonomicznych warunków tworzonych przez system polityczny. Konieczna jest zatem analiza systemu fiskalnego, ocena nastawienia urzędników wobec obywateli i przedsiębiorstw, a także identyfikacja barier ograniczających nadmiernie swobodę aktywności. Ogólnie rzecz biorąc, należy stwierdzić, czy system gospodarczy ma podejście opiekuńcze, a wiec zakłócające przedsiębiorczość podmiotów, czy też tworzy szeroki zakres swobód, przenosząc na obywateli i organizacje odpowiedzialność za ich los. Fałszywie rozumiana opiekuńczość stanowi niestety podstawę kształtowania się postaw roszczeniowych i marnotrawienia zasobów. W analizie gospodarki należy również wykorzystać dane statystyczne, określając strukturę gospodarki. Pomiar udziału sfery publicznej może być dokonany za pomocą np. udziału podmiotów sektora publicznego w liczbie podmiotów, czy też udziału sfery prywatnej w PKB. Można również określać np. poziom wydatków inwestycyjnych lub na działalność $\mathrm{B}+\mathrm{R}$, określając strukturę wydatkowania pieniędzy z podziałem na działalność bieżącą i rozwój. Można też szacować udział sektorów prężnych w gospodarce. Tego typu mierniki są stosunkowo łatwe do wykorzystania i stanowią najpopularniejszy sposób pomiaru sytuacji regionu.

Pomimo swojej złożoności przedstawiony wyżej schemat powinien być w miarę możliwości oraz potrzeb wykorzystywany do uzyskania pełnego obrazu przedsiębiorczości. Zgodzić się należy, że w takim podejściu występuje duża niejednorodność metodologii badawczej nawet w przypadku poszczególnych wymiarów. Dodatkowo wymiary nie są przecież ściśle wyodrębnione i zachodzą na siebie. Dla przykładu kultura współpracy jako miernik organizacji przedsiębiorczej należy przecież do sfery przedsiębiorczości społecznej. Wymienione kwestie nie są jednak zdaniem autora wadą, ale wręcz zaletą proponowanego podejścia. Tworzenie sztucznych granic dla dyskursu naukowego skutkuje bowiem wyłącznie jego oddaleniem od rzeczywistości i zafałszowaniem wyniku. Należy zatem szukać mądrego kompromisu pomiędzy kosztem analizy sytuacji a maksymalną użytecznością uzyskanych wyników.

Pozostaje odpowiedzieć na pytanie, na ile prezentowany schemat analizy przedsiębiorczości może zostać wykorzystany w ocenie potencjału rozwojowego regionu, np. takiego jak województwo podkarpackie. Otóż odpowiedź wydaje się relatywnie prosta. Stosując zasadę 
ekonomiczności badań, można przychylić się do stosowania stosunkowo łatwych do wykorzystania mierników dostarczanych, często nieodpłatnie, przez statystykę publiczną. W przypadku przygotowywania programów rozwojowych, wykorzystujących specyficzne instrumenty (np. system edukacji), można stosować bardziej wyrafinowane badania przedsiębiorczości z wykorzystaniem chociażby kwestionariuszy proponowanych przez autora. Wówczas wysiłek badawczy i poniesione koszty wydają się być uzasadnione koniecznością prawidłowego sformułowania celów oraz później określenia efektów prowadzonych działań.

\section{Potencjał przedsiębiorczy regionu jako jedna z determinant jego pozycji konkurencyjnej - model analizy w kontekście otoczenia globalnego i procesów integracji europejskiej}

Przedstawiony wyżej model analizy przedsiębiorczości wpisuje się w szerszą analizę ukierunkowaną na ocenę potencjału rozwojowego systemu gospodarczego. Potencjał przedsiębiorczy jest bowiem tylko jednym z elementów określających wewnętrzne możliwości kreowania postępu. Rozwija się on bowiem w określonym otoczeniu, na które składają się zarówno potencjał naturalny, jak i infrastruktura ( $w$ tym biznesowa) tworzona przez cywilizację, a więc tzw. potencjał antropologiczny. Generowanie postępu polega więc na wykorzystywaniu poszczególnych składników potencjału rozwojowego systemu gospodarczego w celu przeniesienia go na wyższy poziom cywilizacyjny. Rozwój społeczny i gospodarczy powinien zatem być utożsamiany z procesem stopniowego podnoszenia dobrobytu mieszkańców systemu gospodarczego (Adamowicz 2006), a także z podnoszeniem jakości otoczenia, w którym funkcjonują organizacje tworzone przez obywateli. Opisany wewnętrzny kontekst zmian zachodzących w systemie gospodarczym należy oczywiście poddać nieco bardziej szczegółowej analizie.

Aby dobrze zrozumieć prezentowane przez autora stanowisko odnośnie procesów rozwojowych zachodzących w systemie gospodarczym, należy przyjąć pewne założenia. Otóż przyjąć należy, że jednym z efektów procesów integracji europejskiej oraz globalizacji jest przeniesienie się sfery konkurowania na jednostki terytorialne. Zachodzi oczywiście podstawowe pytanie, czy w istocie taka konkurencja się pojawia, a jeśli tak, to na czym ona polega. Odpowiedź na pierwsze pytanie jest twierdząca, o czym świadczy wiele procesów obserwowanych we współczesnym otoczeniu społeczno-gospodarczym, w tym w również na przykładzie województwa podkarpackiego. Globalny system gospodarczy otwiera kanały komunikacji, które, prócz wymiaru technicznego i kulturowego, mają też oczywiście aspekt ekonomiczny. Wszystkie te trzy aspekty doprowadziły do sytuacji, w której podstawowe składniki kapitału przedsiębiorczego, a więc ludzie i kapitał finansowy, którym dysponują podmioty gospodarcze, mają względną swobodę przemieszczania się. Istnieje zatem strumień kapitału, który przepływa pomiędzy systemami gospodarczymi, z coraz większą łatwością wpływając poprzez swoje decyzje lokalizacyjne na potencjał rozwojowy danego terytorium.

Współcześnie systemy gospodarcze nie mogą opierać swojego rozwoju wyłącznie na potencjale endogenicznym, ponieważ znacząca jego część (chodzi tutaj o potencjał przedsiębiorczy) ma charakter kapitału mobilnego. Zarówno organizacje, jak i ludzie, mogą zmieniać miejsce swojej aktywności, czyli dotychczasową lokalizację. Konkurowanie o kapitał oznacza więc nie tylko przyciaganie ludzi, pieniędzy i organizacji z innych terytoriów, ale także przeciwdziałanie odpływowi kapitału. Biorąc pod uwagę tę sytuację, należy przyjąć pewien schemat analizy procesów rozwoju systemów gospodarczych oraz przenieść owo urynkowione podejście do problemu zarządzania rozwojem systemów gospodarczych na określone działania, mające odzwierciedlenie chociażby w programach rozwojowych. 
Ryc. 3. Wymiary przedsiębiorczości w kontekście rozwoju regionu

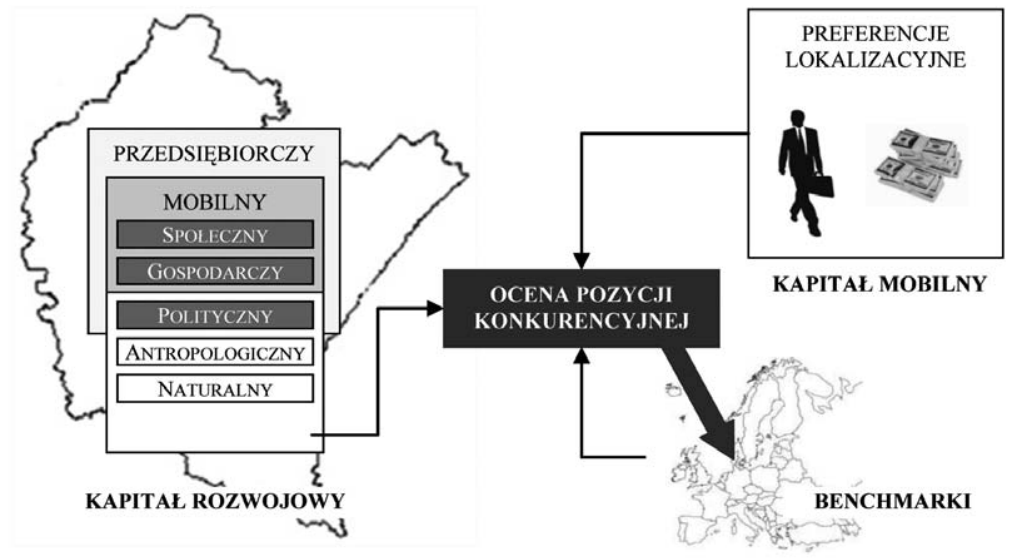

Źródło: na podstawie: Strojny 2008a, s. 311.

Pierwszym z elementów postępowania powinno być określenie potencjału rozwojowego w następujących wymiarach potencjału rozwojowego: społecznym, gospodarczym, politycznym, naturalnym oraz antropologicznym. Pierwsze dwa z wymienionych wymiarów oraz częściowo trzeci tworzą wspomniany wcześniej potencjał przedsiębiorczy systemu gospodarczego. Ponieważ ludzie, relacje między nimi oraz tworzone podmioty gospodarki narodowej określają sposób reakcji na problemy, im wyższy potencjał, tym większa szansa na to, aby wygenerować trwały postęp cywilizacyjny. Przejawia się on m.in. coraz wyższym potencjałem antropologicznym, który obejmuje zarówno materialne, jak i instytucjonalne efekty aktywności człowieka. Najbardziej widocznym efektem jest oczywiście poziom urbanizacji terenu i nasycenia go infrastrukturą ułatwiającą funkcjonowanie ludzi i organizacji (Burchard-Dziubińska M. 2007). Natomiast kapitał naturalny, czyli środowisko naturalne, jest niejako przypisany do danego terytorium, tworząc bazę w postaci określonych możliwości kreowania postępu. Cywilizacja ludzka oraz zbudowany system gospodarczy stwarzają coraz większe możliwość kreowania procesów rozwojowych niezależnie od bogactw naturalnych. Podstawowym stymulatorem rozwoju stają się bowiem gałęzie związane z usługami, nowoczesnymi technologiami, wdrażaniem innowacji, itd. (np. Finlandia) Natomiast z całą pewnością środowisko naturalne wciąż determinuje potencjał rozwojowy wielu systemów gospodarczych (np. Rosji).

Biorąc pod uwage wymienione składniki potencjału, rozwój społeczno-gospodarczy traktować należy jako sumę zmian zachodzących w poszczególnych wymiarach tego potencjału. Oczywiście zmiany poszczególnych wymiarów mogą budować wartość zmiany rozwojowej z określoną wagą. W najprostszym wariancie wagi są jednakowe. Można jednak rozważać wprowadzenie zróżnicowanego udziału w zależności od oceny znaczenia poszczególnych wymiarów dla rozwoju systemu gospodarczego. Dodatkowo można uwzględnić efekt synergii, a więc pozytywnego lub negatywnego dodatkowego efektu wynikającego z kumulacji zmian w potencjale rozwojowym. Można zatem zaproponować bardzo prostą zależność, przedstawioną we wzorze $\mathrm{nr} 1^{2}$.

\footnotetext{
${ }^{2}$ Wzór 1 można stosować również na poziomie wymiarów, wyliczając wartość zmian wymiaru na podstawie zmian atrybutów opisujących ten wymiar. Uwaga ta dotyczy również wzoru 2.
} 
Wzór 1.

$\Delta R_{W}=\sum_{\mathrm{r}=1}^{\mathrm{n}} \Delta W_{i} \times P_{i}$
Gdzie: $\Delta R_{W}$ Rozwój wewnętrzny

$\Delta W_{i}$ Zmiany w wymiarach potencjału

$P_{i} \quad$ Waga wymiaru, przy czym suma wag

wszystkich wymiarów powinna wynieść 1

Oczywiście zjawisko rozwoju obserwowane w wymiarach wewnętrznego potencjału nie oznacza jeszcze poprawy pozycji konkurencyjnej systemu gospodarczego na rynku kapitału mobilnego. Konieczne jest bowiem odniesienie procesów wewnętrznych do procesów rozwoju zachodzących w innych systemach, które traktować należy jako punkt odniesienia. Takie podejście nawiązuje do metody benchmarkingu, którą wykorzystać można w fazie diagnostycznej i monitorująco-ewaluacyjnej w procesie zarządzania rozwojem systemów gospodarczych. Podejście takie opiera się na porównywaniu ważnych cech strukturalnych i funkcjonalnych danego terytorium $\mathrm{z}$ tymi samymi atrybutami terytorium innego, traktowanego jako wzorzec - punkt odniesienia (Kobylińska, Glińska 2008). Współcześnie wydaje się, że zakres poszukiwania benchmarków (owych wzorców) powinien być bardzo szeroki. Trudno jednak w praktyce stosować tak szeroko zakrojone porównania. Dlatego też najczęściej poszukuje się określonych benchmarków w oparciu o wybrane kryteria, co zawęża znacząco obszar porównań. Zatem rzeczywistą miarą atrakcyjności lokalizacyjnej systemu gospodarczego nie jest proces rozwoju wewnętrznego, ale wskaźnik, który można określić jako rozwój netto, a więc różnicę pomiędzy zmianami wewnętrznymi a zmianami w systemach traktowanych jako benchmarki. Stosowny wzór służący do określenia tego wymiaru rozwoju przedstawia wzór 2.

Wzór 2.

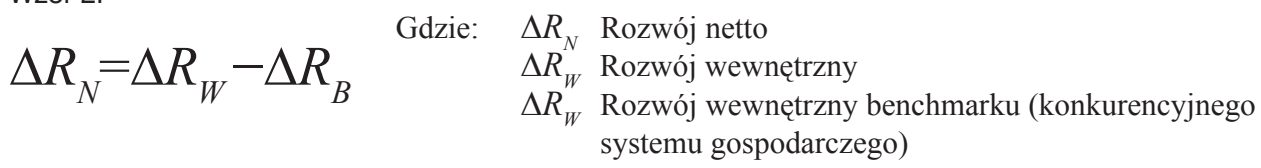

W praktyce analizy rozwoju gospodarczego wymagające wielu badań i oceny jakościowej sprowadza się do stosunkowo prostego wymiaru wartościowego w postaci produkcji. Przyjęty miernik postępu systemów gospodarczych w postaci PKB ma wiele wad, z których zdają sobie sprawę ekonomiści. Łatwość stosowania przeważa jednak i powoduje, że akceptowane jest powszechnie sprowadzenie wszystkich procesów zachodzących w systemie do wartości wytworzonych dóbr i usług. Oczywiście proponowane w niniejszym artykule podejście do analizy nie jest alternatywą względem PKB. Prowadzenie pomiarów poszczególnych składników potencjału rozwojowego (a zwłaszcza jej najistotniejszego elementu, czyli potencjału przedsiębiorczego) jest zajęciem żmudnym, trudnym i zróżnicowanym metodologicznie. Dlatego też traktować je należy jako rozwinięcie analiz poczynionych w oparciu o PKB. Zatem proponowany tok postępowania obejmuje:

1. Określenie zmian zachodzących wewnątrz systemu $\left(\Delta R_{W}\right)$ dokonywane jest zgodnie z metodyką wyliczania PKB w danym kraju.

2. Sprowadzenie rozwoju do wartości netto $\left(\Delta R_{N}\right)$ poprzez dobór benchmarków oraz odniesienie wartości zmian PKB porównywanych podmiotów. Dla regionów naturalnym punktem odniesienia mogą być np. inne regiony danego kraju.

3. Określenie pozycji konkurencyjnej systemu gospodarczego poprzez uplasowanie danego systemu gospodarczego w rankingu na podstawie oceny rozwoju netto.

4. Podjęcie działań zmierzających do wyjaśnienia przyczyn powodujących osiągnięcie określonej pozycji konkurencyjnej poprzez badania poszczególnych wymiarów potencjału rozwojowego. 
5. Przygotowanie i wdrożenie instrumentów wspierających rozwój poszczególnych wymiarów potencjału wewnętrznego, a przez to poprawa możliwości utrzymania bądź pozyskania z zewnątrz kapitału mobilnego.

Przedstawiona ścieżka postępowania powinna charakteryzować każdy proces programowania rozwoju systemu gospodarczego. Oczywiście w przypadku, gdy statystyka nie dostarcza wyliczeń PKB (np. dla samorządów lokalnych), konieczne jest przyjęcie alternatywnych mierników rozwoju. Wydaje się, że przedstawiony tok postępowania staje się coraz częściej praktyką, choć wciąż jako podstawowy miernik rozwoju traktuje się wskaźnik rozwoju wewnętrznego, a nie netto. Ponadto bardzo często w analizach stanu nie przeprowadza się badań porównawczych, zawężając ocenę do sytuacji wewnętrznej. Konieczne jest zatem zwrócenie baczniejszej uwagi na sekwencję działań oraz pewnego rodzaju dyscyplinę w realizacji każdego z wymienionych kroków.

\section{Charakterystyka wybranych mierników potencjału przedsiębiorczego województwa podkarpackiego na tle innych województw}

Analiza potencjału przedsiębiorczego województwa podkarpackiego przeprowadzona będzie według sugerowanego wcześniej schematu. Jako punkt wyjścia należy potraktować analizę zmian rozwojowych w regionie wykonaną na podstawie podstawowego wskaźnika, a więc zmian wartości PKB. Oczywiście należy tutaj przyjąć dwa poziomy oceny sytuacji, a mianowicie pomiar rozwoju wewnętrznego oraz pomiar rozwoju netto w odniesieniu do przyjętych benchmarków. Autor przyjął, że porównanie odbywać się będzie wobec wszystkich regionów w Polsce na podstawie danych GUS za okres 1999-2007. Wykorzystano w tym celu matrycę (tabelę krzyżową) i porównano każde województwo ze wszystkimi pozostałymi, obliczając różnicę pomiędzy zmianami. W ten sposób określono dystans rozwojowy, który powstał pomiędzy badanymi regionami na przestrzeni analizowanych lat.

Przechodząc do oceny wewnętrznego wymiaru rozwoju, należy podkreślić, że w latach 1999-2007 nastapił w Polsce na poziomie całego kraju oraz poszczególnych regionów zdecydowany wzrost wartości PKB (ryc. 4). Przyrost PKB kraju w cenach bieżących wyniósł $76,8 \%$, zaś po uwzględnieniu wpływu inflacji, czyli realnie - 46,2\%. Właśnie wartości realne będą podstawą oceny procesów rozwojowych Podkarpacia. W badanym województwie na przestrzeni przyjętego okresu PKB wzrósł o 35,4\%. Oznacza to oczywiście, że gospodarka regionu potrafi poprawiać swoją sytuację, doprowadzając do stopniowego zwiększania produkcji. Warto jednak zwrócić uwagę, że wartość zmiany $\left(\Delta R_{W}\right)$ jest zdecydowanie niższa niż w większości pozostałych województw. Największe zmiany zanotowano w województwie mazowieckim, które powiększyło swoją realną zdolność produkcyjną o blisko 60\%. Inne wiodące regiony to: dolnośląskie, wielkopolskie i małopolskie. Badany region pod względem tempa powiększania realnej produkcji znajduje się na jednym z ostatnich miejsc, mając sytuację podobną do warmińsko-mazurskiego i lubelskiego oraz zdecydowanie lepszą iż województwo zachodniopomorskie.

Wyliczone wartości zmian w przyjętym do analizy okresie dają podstawę do określenia rzeczywistego tempa rozwoju regionów, czyli rozwoju netto $\left(R_{N}\right)$. Ponieważ benchmarkami będą tutaj pozostałe regiony Polski, można już bardzo wyraźnie określić, które regiony z punktu widzenia przyjętego wskaźnika rzeczywiście się rozwijają, zwiększając dystans do pozostałych. W celu oceny tego zjawiska przygotowano najpierw wartości wskaźników rozwoju netto dla każdego województwa, odnosząc to województwo do wszystkich pozostałych. 
Ryc. 4. Procentowe zmiany realnego PKB w województwach na tle kraju na przestrzeni lat 1999-2007 (wartość rozwoju wewnętrznego $-\Delta \mathrm{R}_{\mathrm{w}}$ )

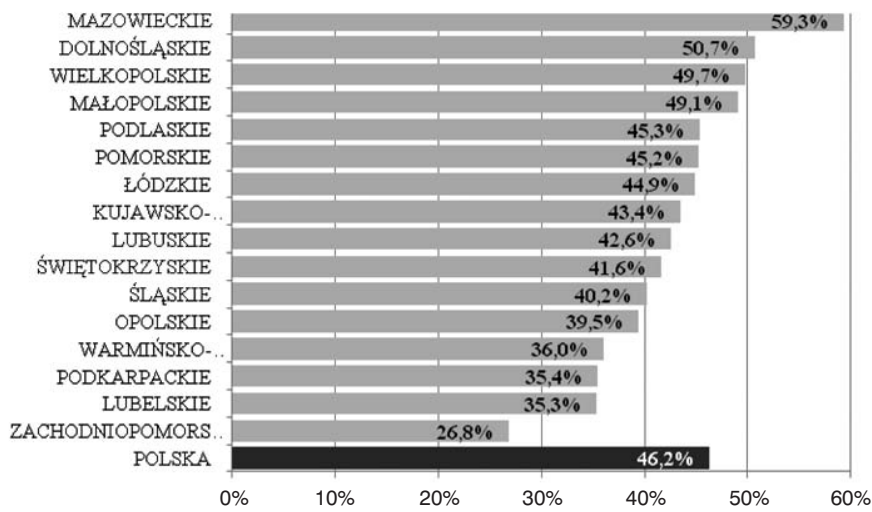

Źródło: opracowanie własne na podstawie danych GUS.

Następnie wyliczono wartość średnią dystansu wobec innych województw. W ten sposób powstał miernik określający tempo zmian rozwojowych odniesione do otoczenia traktowanego jako pozostała część kraju. Wartości dodatnie oznaczają, że dystans pomiędzy danym województwem a pozostałymi wzrasta. Natomiast pojawienie się wartości ujemnych oznacza, że inne regiony rozwijają się szybciej, a wiec de facto dany region z perspektywy zewnętrznej nie podlega procesom rozwojowym, a wręcz przeciwnie - regresowi.

Spośród regionów Polski w największym stopniu dystans wobec innych zwiększa region mazowiecki. Średnia wartość współczynnika rozwoju netto w badanych latach wyniosła 17,6\%. Trzy pozostałe regiony, wymienione wyżej jako wiodące, również zwiększają średnio dystans rozwojowy wobec pozostałych. Wartość wskaźnika rozwoju netto wynosi ok. 7-8\%. Wśród województw, które pogarszają swoją pozycję konkurencyjną, wymienić należy również podkarpackie. Średnia strata do pozostałych wynosi 7,9\%. Gorszą sytuację obserwować jeszcze tylko w lubelskim oraz zachodniopomorskim. W tym ostatnim wypadku opóźnienie w stosunku do pozostałych jest szczególnie widoczne - wynosi aż 17,1\%. Wartości $\Delta R_{N}$ dla wszystkich województw Polski przedstawia ryc. 5.

Ryc. 5. Wartość średnia rozwoju netto wypracowanego przez województwa względem pozostałych regionów kraju na przestrzeni lat 1999-2007 (wartość zmian współczynnika rozwoju netto $-\Delta \mathrm{R}_{\mathrm{N}}$ )

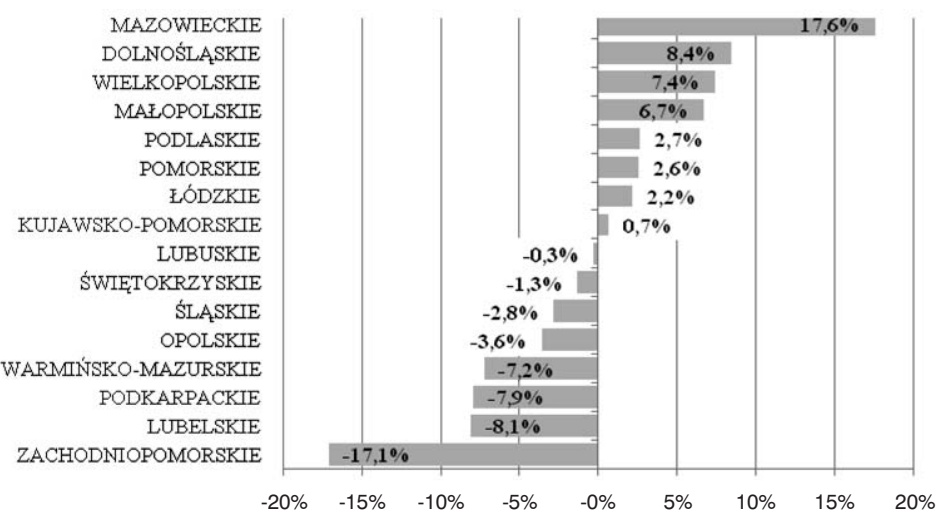

Źródło: opracowanie własne na podstawie danych GUS. 
Warto zwrócić uwagę, że strata rozwojowa charakteryzuje głównie regiony słabo rozwinięte lub posiadające duże problemy np. ze strukturą gospodarki (np. niskotowarowe rolnictwo przy jednocześnie dużym zatrudnieniu ludności w produkcji rolnej). Regiony lepiej rozwinięte mają tendencję do dalszego zwiększania dystansu rozwojowego, ponieważ ich pozycja konkurencyjna jest zdecydowanie lepsza. Oznacza to, że mają one tendencję do zatrzymywania kapitału mobilnego u siebie, a ponadto do przyciagania kapitału zewnętrznego. Widoczne jest to chociażby w procesach migracyjnych pomiędzy regionami. Województwa takie jak mazowieckie, dolnośląskie, wielkopolskie czy małopolskie drenują pozostałe regiony, pozyskując stamtąd przede wszystkim osoby młode, prężne a więc najprawdopodobniej posiadające również wysoki potencjał przedsiębiorczości. Skoro więc podstawowa sfera kapitału rozwojowego województw rozwijających się wolniej niż pozostałe jest osłabiana, to nie może dziwić sukcesywne narastanie dystansu rozwojowego.

Szczegółowe wyniki analizy sytuacji w województwie podkarpackim z wykorzystaniem wskaźnika RN przedstawia tab. 1. Największy dystans w wysokości blisko $25 \%$ dotyczy porównania Podkarpacia z województwem mazowieckim. Do pozostałych regionów lepiej rozwiniętych badany region traci po kilkanaście procent. Wydaje się, że cztery wiodące województwa w sposób trwały zbudowały swoją przewagę konkurencyjną i bardzo trudno będzie znaleźć sposób nawet na to, aby ten dystans w najbliższych kilku lub kilkunastu latach zmniejszać, nie mówiąc już o osiagnięciu podobnego poziomu rozwoju. Podkarpacie może natomiast skutecznie konkurować z takimi regionami, jak lubelskie, warmińsko-mazurskie, opolskie czy zachodniopomorskie. Przyjęcie odpowiednich instrumentów oddziaływania na przedsiębiorczość w skali regionu mogłoby również poprawić sytuację Podkarpacia, a więc przyśpieszenie rozwoju względem innych województw, w ciagu najbliższej dekady.

Wyliczanie wartości RW i RN w oparciu o zmiany PKB, jak już zostało to podkreślone, mimo że wygodne, stanowi zdecydowane uproszczenie. Sprowadzenie niezliczonych procesów rozwojowych do postaci wzrostu gospodarczego nie pozwala na dogłębną analizę przyczyn sytuacji rozwojowej, w jakiej znajduje się badany region. Dlatego też, zgodnie z przyjętym schematem postępowania, należy ocenić atrybuty poszczególnych wymiarów potencjału rozwojowego oraz zachodzących $\mathrm{w}$ nich zmian. W niniejszym artykule autor skupi się na ocenie potencjału przedsiębiorczego z wykorzystaniem przyjętego modelu analizy przedsiębiorczości. Zgodnie z nim należy scharakteryzować:

- przedsiębiorcze cechy składające się na osobowość modalną mieszkańców regionu,

- parametry społeczności regionu pod kątem relacji oraz zachowań społecznych (przedsiębiorczość społeczną),

- sposób funkcjonowania przedsiębiorstw zlokalizowanych w regionie, ich nastawienie na rozwój, innowacyjność itd.

- specyfikę struktury branżowej gospodarki oraz regulacje wspierające zachowania wolnorynkowe i swobodę obywatelską oraz gospodarczą.

Określenie potencjału przedsiębiorczego na poziomie indywidualnym wymaga podjęcia szerszych badań z wykorzystaniem wspomnianego już kwestionariusza. Autor dysponuje jedynie badaniami prowadzonymi na próbach celowych (przedsiębiorców, studentów, rodzin). Nie są to natomiast badania reprezentatywne dla regionu. Wyniki prowadzonych badań dają jednak pogląd na sytuację i pozwalają na sformułowanie bardzo ostrożnych sądów. Dla przykładu w badaniu przedsiębiorców (grupy o potencjalnie wysokim poziomie przedsiębiorczości indywidualnej) wartości wskaźnika ogólnego oraz wskaźników opisujących poszczególne atrybuty przedsiębiorczości indywidualnej, a więc motywację sukcesu, wewnątrzsterowność i zdolności intelektualne, przyjmują wartości 64-67 pkt. w skali od 0 do 100. Należy przy 
tym pamiętać, że kwestionariusz skonstruowany jest w ten sposób, że wartości poniżej 50 pkt. mogą wskazywać na zachowania nawet przeciwne do przedsiębiorczych. Trudno oczywiście odnieść sytuację Podkarpacia do innych województw ze względu na brak szerzej zakrojonych badań identyfikujących wartość potencjału przedsiębiorczości indywidualnej.

Tab. 1. Wartość rozwoju netto wypracowana przez województwo podkarpackie względem pozostałych regionów kraju na przestrzeni lat 1999-2007 (wartość rozwoju netto - RN)

\begin{tabular}{|c|c|c|}
\hline \multicolumn{2}{|c|}{ Benchmarki } & \multirow{2}{*}{$\begin{array}{l}\text { PODKARPACKIE } \\
\qquad\left(\Delta \mathbf{R}_{\mathrm{w}}=35,4 \%\right) \\
\text { rozwój netto }\left(\mathrm{R}_{\mathrm{N}}\right)\end{array}$} \\
\hline województwo & rozwój wew. benchmarków $\left(R_{B}\right)$ & \\
\hline ZACHODNIOPOMORSKIE & $26,8 \%$ & $8,6 \%$ \\
\hline LUBELSKIE & $35,3 \%$ & $0,1 \%$ \\
\hline WARMIŃSKO-MAZURSKIE & $36,0 \%$ & $-0,6 \%$ \\
\hline OPOLSKIE & $39,5 \%$ & $-4,0 \%$ \\
\hline ŚLAૃSKIE & $40,2 \%$ & $-4,8 \%$ \\
\hline ŚWIĘTOKRZYSKIE & $41,6 \%$ & $-6,2 \%$ \\
\hline LUBUSKIE & $42,6 \%$ & $-7,1 \%$ \\
\hline KUJAWSKO-POMORSKIE & $43,4 \%$ & $-8,0 \%$ \\
\hline ŁÓDZKIE & $44,9 \%$ & $-9,5 \%$ \\
\hline POMORSKIE & $45,2 \%$ & $-9,8 \%$ \\
\hline PODLASKIE & $45,3 \%$ & $-9,9 \%$ \\
\hline MAŁOPOLSKIE & $49,1 \%$ & $-13,7 \%$ \\
\hline WIELKOPOLSKIE & $49,7 \%$ & $-14,3 \%$ \\
\hline DOLNOŚLĄSKIE & $50,7 \%$ & $-15,3 \%$ \\
\hline MAZOWIECKIE & $59,3 \%$ & $-23,9 \%$ \\
\hline Średnia & $43,3 \%$ & $-7,9 \%$ \\
\hline
\end{tabular}

Źródło: opracowanie własne na podstawie danych GUS.

Kolejny obszar przenosi analizę na poziom całej społeczności, dla której możliwe jest identyfikowanie odpowiednich atrybutów odnoszących się do relacji między ludźmi oraz do pewnych charakterystycznych zachowań społeczności. W niniejszym artykule autor skupi się wyłącznie na cechach społeczności możliwych do opisania na podstawie danych dostarczonych przez statystykę publiczną. Drugim kanałem zbierania danych pierwotnych mógłby być odpowiednio sformułowany kwestionariusz wykorzystywany cyklicznie, np. na podobnej zasadzie jak prowadzony jest proces diagnozy społecznej realizowany przez Polskie Towarzystwo Statystyczne. Tylko na takiej podstawie możliwe będzie stworzenie podstawy porównawczej uzupełniającej tradycyjny zbiór danych statystycznych. Spośród dostępnych mierników przedsiębiorczości na poziomie społeczności regionów autor wybrał te, które mogą być traktowane jako przykładowe mierniki, możliwe do wykorzystania w procesie diagnostycznym oraz monitoringu i ewaluacji programów rozwojowych.

Pierwszym ze wskaźników, który na poziomie całego społeczeństwa może stanowić atrybut potencjału przedsiębiorczego, jest współczynnik aktywności ekonomicznej ludności. Jest 
to standardowy miernik określający, jaka część ludności danego terytorium skłonna jest do uczestniczenia aktywnie w procesach społeczno-gospodarczych. Procentowa zmiana tego wskaźnika w latach 1999-2008 przedstawiona jest na ryc. 6.

Zmiany niemal we wszystkich województwach mają charakter regresu, który objawia się spadkiem współczynnika od kilku do kilkunastu procent na przestrzeni analizowanych lat. Najmniejszy regres w obszarze rozpatrywanego atrybutu obserwować można w województwie świętokrzyskim - 0,9\%. Natomiast największy spadek współczynnika notowany jest w województwie zachodniopomorskim. Jedynym regionem, w którym nastapił rozwój w obszarze opisywanym niniejszym atrybutem, jest województwo mazowieckie - wzrost udziału osób aktywnych ekonomicznie wyniósł 1,9\%. Województwo podkarpackie należy do regionów, w których regres jest relatywnie niewielki i wynosi 4,7\%. Przekłada się to na analizę z wykorzystaniem benchmarkingu. Okazuje się, że na przestrzeni lat sytuacja województwa względem innych poprawiła się, choć bardzo nieznacznie. Średnia wartość współczynnika rozwoju netto wynosi $+0,9 \%$. Wartość ta wynika z tego, że w dużej liczbie regionów spadek współczynnika aktywności zawodowej był zdecydowanie szybszy niż na Podkarpaciu.

Ryc. 6. Zmiana współczynnika aktywności ekonomicznej ludności na przestrzeni lat 1999-2008

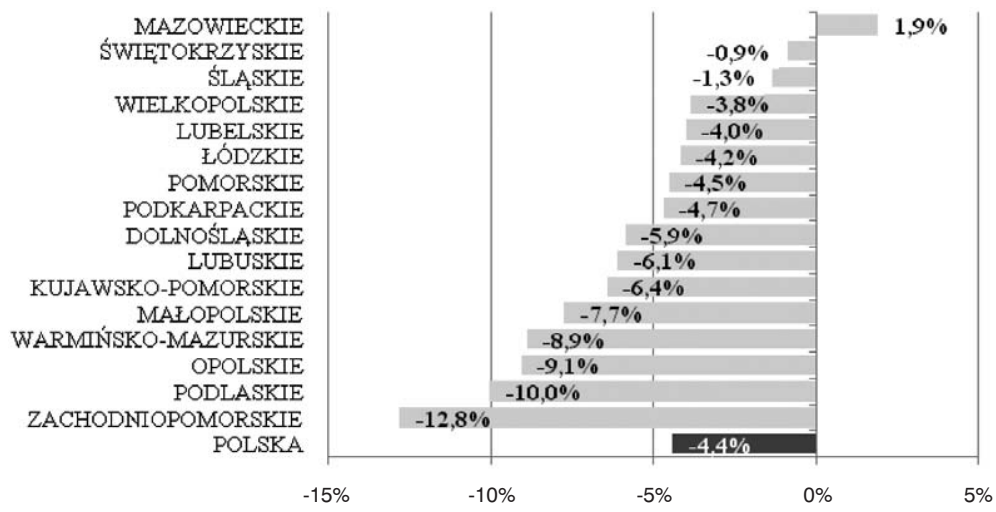

Źródło: opracowanie własne na podstawie danych GUS.

Kolejny atrybut społeczeństwa przedsiębiorczego mierzony jest za pomocą wskaźnika określającego liczbę podmiotów gospodarki narodowej przypadających na 1 tys. mieszkańców. Być może nieco trafniejszym wyborem byłoby stosowanie np. liczby podmiotów prowadzonych jako osoba fizyczna lub liczby podmiotów z sektora MŚP. Tego typu alternatywne mierniki można rozważać jako uzasadnione, jednak wąskie ramy niniejszego opracowania nie pozwalają na tak obszerną analizę. Procentowe zmiany użytego w opracowaniu miernika za okres 1999-2008 przedstawia ryc. 7.

W Polsce widoczna jest sukcesywna poprawa sytuacji polegająca na stopniowym wzroście liczby podmiotów gospodarki narodowej przypadających na 1 mieszkańca. Wynika to w głównej mierze ze wzrostu liczby podmiotów rejestrowanych w systemie REGON, ale również po części ze spadku liczby ludności w niektórych regionach. Największe zmiany obserwuje się w opolskim i świętokrzyskim: 37-38\%. Te relatywnie małe regiony charakteryzują się bardzo dużą dynamiką pozytywnych zmian. Najgorzej wypadają województwo podkarpackie i podlaskie - odpowiednio $16,3 \%$ oraz $14,7 \%$. Badany region traci więc na przestrzeni analizowanych lat wobec pozostałych regionów. Średnio wartość netto miernika wobec benchmarków wynosi $-8,2 \%$. 
Ryc. 7. Zmiana współczynnika liczby podmiotów gospodarczych przypadających na 1000 mieszkańców na przestrzeni lat 1999-2008

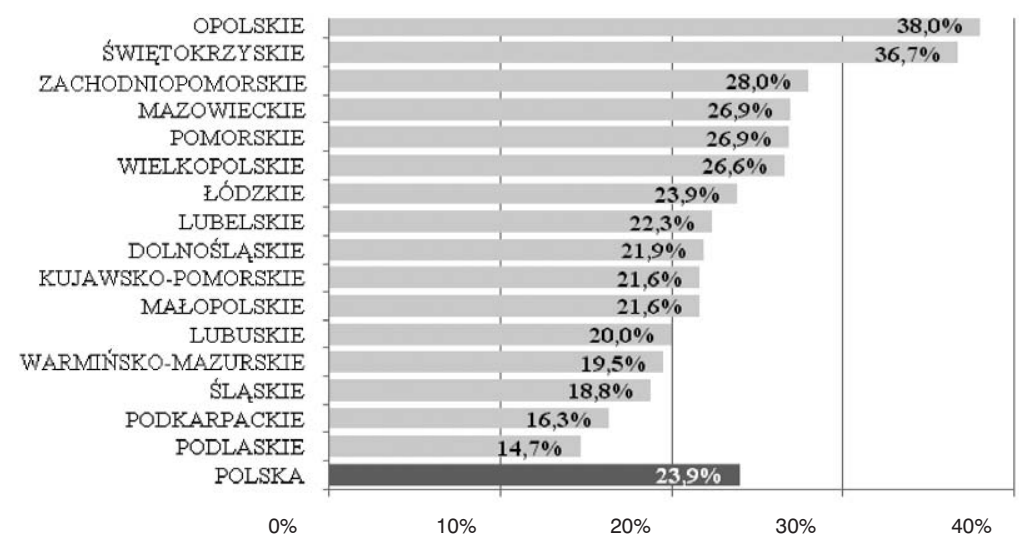

Źródło: opracowanie własne na podstawie danych GUS.

Oczywiście w tak krótkim artykule nie sposób przedstawić szerszej analizy oraz agregować atrybutów do poziomu zmian w ramach wymiaru z wykorzystaniem zaproponowanych przez autora wzorów. Ograniczona zostanie też analiza innych atrybutów, które mają również duże znaczenie i charakteryzują potencjał przedsiębiorczości społeczeństwa. Autor sugeruje, aby brać pod uwagę m.in. wskaźniki migracji, liczbę organizacji pozarządowych przypadających na 1000 mieszkańców, frekwencję w wyborach (warto porównywać zmiany frekwencji w wyborach tego samego rodzaju). Można zastanawiać się też nad użyciem takich wskaźników, jak odsetek osób z wyższym wykształceniem czy odsetek osób zagrożonych ubóstwem (jako atrybut odwrotny).

Kolejny z wymienionych obszarów przedsiębiorczości dotyczy potencjału organizacji. Autor, podobnie jak w przypadku przedsiębiorczości indywidualnej, prowadził badania na próbach celowych. Wartości przyjętych atrybutów, a więc myślenia strategicznego, kultury współpracy i innowacyjności kształtują się pomiędzy 58 a 64 pkt. w skali 0-100 pkt. Oczywiście analiza sytuacji w skali regionu wymagałaby prowadzenia badań na próbie losowej, zaś określenie zmian powtarzania badań w odstępach np. rocznych. Istnieją oczywiście badania, które częściowo lub w całości poświęcone są ocenie potencjału przedsiębiorczego przedsiębiorstw, z różnicowaniem regionalnym. Przykładem mogą być raporty o stanie sektora MŚP realizowane przez zespoły powoływane przez PARP. Mają one jednak zazwyczaj charakter analiz sektorowych, a więc w przyjętym przez autora modelu nadają się raczej do oceny sytuacji potencjału przedsiębiorczego na poziomie gospodarki (w zakresie oceny jej struktury).

Przedsiębiorczość na poziomie gospodarki jest również możliwa do oceny za pomocą danych statystycznych. Proponuje się tutaj przyjąć mierniki odwołujące się do atrybutów struktury gospodarki sprzyjające szybkiej reakcji całego systemu na wyzwania globalne. Oczywiście dokładna diagnoza gospodarki wymaga bardziej pogłębionych studiów, co już zostało podkreślone $\mathrm{w}$ niniejszym artykule. $\mathrm{W}$ ramach tak niewielkiego opracowania przedstawione zostaną tylko wybrane mierniki wraz z ich interpretacją. Są one relatywnie łatwe do skonstruowania i przedstawiają dużą wartość poznawczą. Oczywiście poziom szczegółowości, a zatem i liczba mierników zależą od zakresu badania oraz przyjętych celów badawczych.

Pierwszy z przykładowych atrybutów przedsiębiorczości gospodarki pozwala ocenić, jaką popularnością cieszy się najbardziej wyrafinowana forma działalności gospodarczej, a więc 
spółka handlowa. Przyjęty miernik określa procentowy udział przedsiębiorstw działających w tego typu formie organizacyjno-prawnej w ogólnej liczbie podmiotów gospodarki narodowej. Zmiany procentowe tego wskaźnika zmierzono na przestrzeni okresu 1999-2008, otrzymują wartość procentową zmian. Wyniki przedstawiono na ryc. 8.

Ryc. 8. Zmiana udziału spółek handlowych w podmiotach gospodarki narodowej na przestrzeni lat 1999-2008

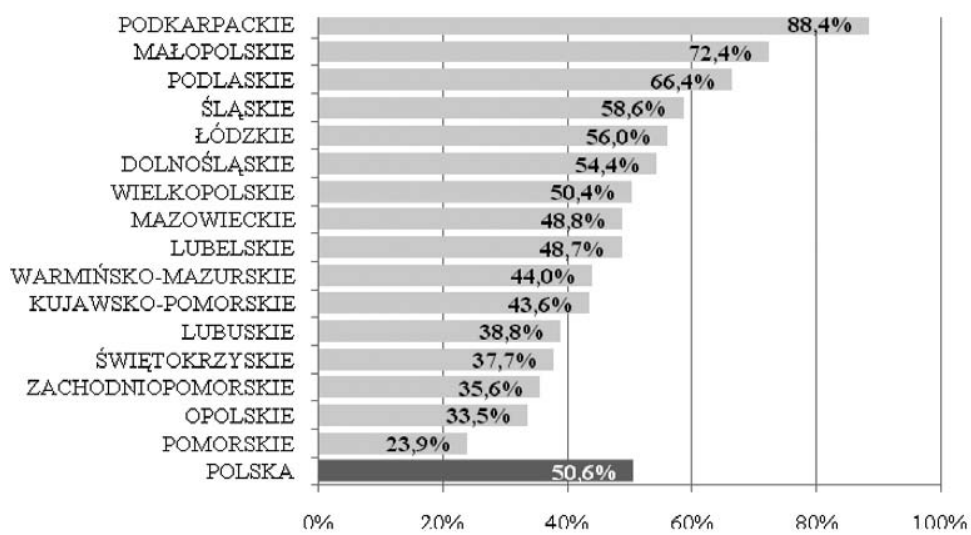

Źródło: opracowanie własne na podstawie danych GUS.

W Polsce na przestrzeni badanego okresu obserwuje się rosnącą popularność prowadzenia działalności w postaci spółki handlowej. Oznacza to większą profesjonalizację zarządzania przedsiębiorstwem oraz z całą pewnością wiąże się z rosnącą świadomością biznesową społeczeństwa, a także wielkością kapitału. Wśród województw obserwuje się jednak dużą różnorodność jeśli chodzi o zakres zmian - przyrosty udziału omawianego typu przedsiębiorstw wahają się między 24 a 88\%. Najlepiej wypada Podkarpacie, najgorzej zaś województwo pomorskie. Mazowieckie, w którym udział spółek handlowych jest największy (blisko 12\%) notuje znacznie wolniejszą poprawę wartości tego wskaźnika, przez co dystans rozwojowy Podkarpacia do wiodącego regionu zmniejsza się. Średnio dynamika zmian była wyższa o ponad 40\% niż w innych regionach kraju.

Kolejny atrybut gospodarki przedsiębiorczej to wartość nakładów inwestycyjnych wynikająca z przyjętych strategii rozwoju. Badając przedsiębiorczość na poziomie organizacji, ustala się zdolność podmiotów do określenia celów strategicznych oraz nastawienie na rozwój. Jednym z jego przejawów jest podejmowanie działalności inwestycyjnej ukierunkowanej na podniesienie potencjału wytwórczego, innowacyjności itd. W skali całej gospodarki kumulują się działania podejmowane w poszczególnych podmiotach. Dlatego też należy uznać, że prezentowany atrybut należy do dość istotnych składowych przedsiębiorczości na poziomie systemu gospodarczego. Jako miernik atrybutu przyjęto wartość nakładów inwestycyjnych w gospodarce narodowej. Wartości zostały skorygowane o wskaźnik inflacji, czyli urealnione. Można oczywiście się zastanawiać nad bardziej szczegółowym miernikiem - np. wydatkami inwestycyjnymi wyłącznie w sektorze prywatnym bądź w określonej gałęzi gospodarki. Zależeć to będzie od intencji badacza oraz wymaganej szczegółowości analizy. Przyjęto, podobnie jak w poprzednich atrybutach, okres od 1999 do $2008 \mathrm{r}$.

W Polsce obserwuje się sukcesywny wzrost wartości nakładów inwestycyjnych realizowanych przez różnego typu podmioty gospodarki narodowej. Sytuacja ta jest jednak bardzo 
zróżnicowana regionalnie. Wzrost wydatków na przestrzeni analizowanego okresu wynosi od niespełna 1 do $95 \%$. W województwie opolskim notuje się natomiast spadek realnych nakładów inwestycyjnych o $0,2 \%$. Największe zmiany obserwuje się w województwie warmińsko-mazurskim - 95,3\%. Podkarpackie jest natomiast regionem o przyroście inwestycji na poziomie blisko 50\%. Wyniki analizy dla wszystkich regionów przestawia ryc. 9. W przypadku analizy porównawczej sytuacja badanego województwa nie zmieniła się w stosunku do benchmarków.

Ryc. 9. Zmiana wartości nakładów inwestycyjnych w gospodarce narodowej na przestrzeni lat 1999-2008

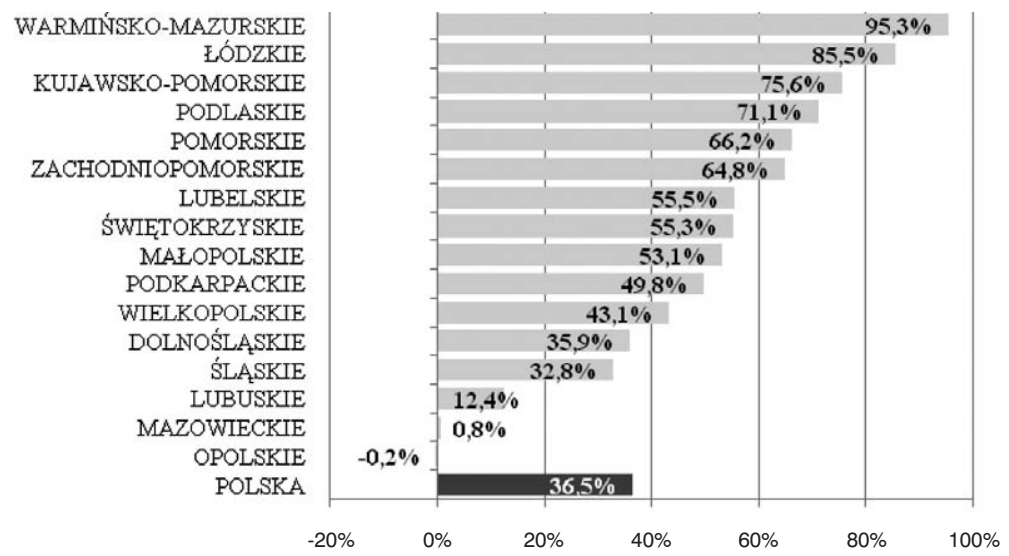

Źródło: opracowanie własne na podstawie danych GUS.

Innym atrybutem, który można wykorzystać na poziomie gospodarki, jest nastawienie gospodarki na innowacyjność. Aktywność w tym zakresie jest szczególnie ważna z punktu widzenia przedsiębiorczości, powoduje bowiem wytworzenie narzędzi konkurowania na rynku globalnym. Jednym z mierników, który może tutaj zostać wykorzystany, jest wartość nakładów na działalność innowacyjną. Ze względu na ograniczenia dostępu do danych ograniczono się do przedsiębiorstw przemysłowych oraz do okresu 2002-2008. Przyjęto oczywiście wartości skorygowane o zmianę cen w analizowanym okresie.

Ogólnie rzecz biorąc, można zaobserwować w Polsce wzrastający potencjał innowacyjny wyrażony przyrostem realnej wartości nakładów na ten cel. Tempo zmian w regionach jest jednak bardzo duże. Zdecydowanym liderem w skali kraju jest województwo łódzkie, gdzie przyrost wyniósł prawie 360\%. Dystans tego regionu do mazowieckiego zmniejszył się znacząco na przestrzeni lat. Inne regiony, w których przyrosty przekraczają 100, a nawet 200\%, to: pomorskie, kujawsko-pomorskie, mazowieckie i podlaskie. Podkarpacie w tym obszarze rozwija się stosunkowo wolno - wydatki na innowacje wzrosły tutaj o 39,4\%. Przyrost ten jednak był słabszy niż w innych województwach (szczególnie tych z czołówki), co powoduje, że średnio zmiany były mniej dynamiczne niż w pozostałej części kraju o wartość 36,1\%. Oczywiście wartość ta wynika z dużej dynamiki w regionach wiodących. Podkarpacie rozwija się bowiem szybciej w zakresie tego atrybutu niż 9 województw. Szczególnie trudna sytuacja dotyczy województwa świętokrzyskiego, w którym realne wydatki na innowacje spadły o $58 \%$. Wyniki analizy przedstawia ryc. 10 .

Oprócz wymienionych wyżej atrybutów i proponowanych dla nich mierników przedsiębiorczość na poziomie gospodarki można oceniać, wykorzystując bogaty zestaw danych statystycznych. Warto zwrócić uwagę choćby na udział sektora prywatnego w wypracowywaniu 
wartości dodanej regionu. Można również oceniać udział sektora przedsiębiorstw średnich i dużych w ogólnej liczbie przedsiębiorstw. Ważnym atrybutem może być również np. udział sektora usług czy spółek z kapitałem zagranicznym w liczbie przedsiębiorstw ogółem. Wszystkie te i szereg innych atrybutów należy używać w sposób zgodny z metodologią oraz dla wybranych okresów.

Ryc. 10. Zmiana wartości nakładów na działalność innowacyjną w przedsiębiorstwach przemysłowych na przestrzeni lat 2002-2008

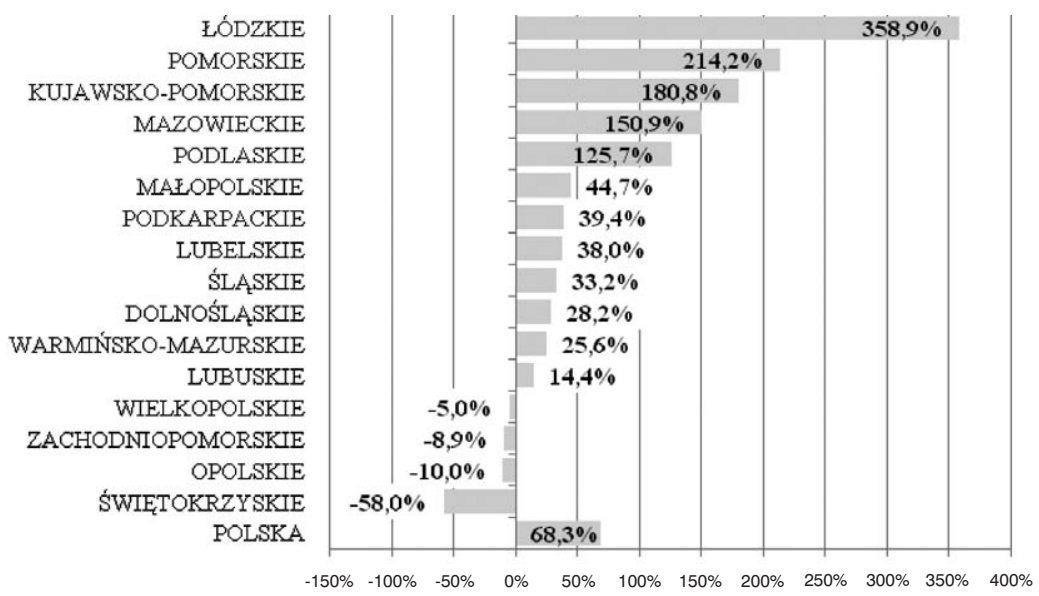

Źródło: opracowanie własne na podstawie danych GUS.

Podsumowując przeprowadzoną analizę, należy zwrócić uwagę na kilka rzeczy. Po pierwsze, artykuł zarysowuje bardzo ogólnie, jak mógłby wyglądać system pomiaru i oceny pozycji konkurencyjnej systemu gospodarczego. Autor nie dysponuje obecnie jeszcze spójnym i całościowym podejściem do problemu pomiaru potencjału rozwojowego, a w szczególności potencjału przedsiębiorczości. Prezentowane podejście jest próbą zabrania głosu w dyskusji i przedstawienie podejścia, które w założeniach ma za zadanie holistyczną ocenę przedsiębiorczości w sposób być może nawet systemowy. Taka ocena potencjału rozwojowego daje podstawę do określenia szans na zbudowanie dobrej pozycji konkurencyjnej w otoczeniu europejskim i globalnym.

Przeprowadzona, bardzo okrojona analiza przedsiębiorczości daje podstawę do wyciagnięcia kilku wniosków o sytuacji Podkarpacia w kontekście integracji europejskiej i globalizacji. Badany region należy do najbiedniejszych nie tylko w Polsce, ale również w całej Unii Europejskiej. Analiza potencjału przedsiębiorczego nie pozwala na wystawienie ocen jednoznacznie negatywnych czy pozytywnych. Nie ulega jednak wątpliwości, że region znajduje się w trudnej sytuacji, a jego pozycja konkurencyjna na rynku kapitału mobilnego jest dość słaba. Przejawia się to zarówno w procesach migracyjnych, jak i w odpływie niektórych przedsiębiorstw. Podkarpacie relatywnie słabo radzi sobie ze ściąganiem kapitału zewnętrznego oraz nowych mieszkańców z zewnątrz. Fundusze unijne i polityka wyrównywania potencjałów za pomocą dodatkowych środków powoduje z całą pewnością podsycenie procesów rozwojowych. Są one jednak zbyt słabe, aby zmniejszyć dystans rozwojowy do pozostałych regionów, chociażby w kraju, nie mówiąc o bardziej rozwiniętych regionach Europy. W skali globalnej Podkarpacie nie może również liczyć w najbliższych latach na podniesienie pozycji 
konkurencyjnej. Poziom przedsiębiorczości i potencjał kreowania innowacji wciąż w tym regionie jest zbyt mały, aby zmienić sytuację. Oznacza to, że racjonalnie rzecz ujmując, na przestrzeni następnych kilku, a być może nawet kilkunastu lat trudno wyobrazić sobie znaczące przyśpieszenie w dochodzeniu do średniej zamożności w UE, mierzonej chociażby wartością PKB per capita. Bez bardzo radykalnych programów rozwojowych trudno będzie dokonać skokowego postępu w regionie. Jest to tymczasem jedyna szansa na poprawę pozycji konkurencyjnej badanego województwa.

\section{Podsumowanie}

Artykuł w swoich ograniczonych ramach przedstawia dość złożony, ale niezwykle ważny proces. Polega on na systemowym podejściu do oceny potencjału rozwojowego, a na tej podstawie do formułowania wniosków dotyczących celów zarządzania strategicznego. Przeprowadzona bardzo uproszczona i wybiórcza analiza sytuacji Podkarpacia wskazuje jednak, w jaki sposób można skorzystać z modelowych podejść prezentowanych w początkowych częściach artykułu. Ważne wydaje się też zwrócenie uwagi na konieczność stosowania benchmarkingu z wykorzystaniem np. zmodyfikowanych wskaźników, które określone zostały przez autora jako wskaźniki rozwoju netto, a więc określające realną zmianę dystansu pomiędzy systemami gospodarczymi. Usystematyzowanie podejścia i stworzenie systemów pomiaru przedsiębiorczości na poziomach podmiotów (indywidualnej i organizacji) dałoby podstawę do wdrożenia prezentowanego podejścia w życie.

\section{Literatura}

1. Adamowicz M., 2006, Nowe tendencje w zarzadzaniu rozwojem lokalnym [w:] Rola samorzqdu w zarzq̨dzaniu rozwojem lokalnym i regionalnym, red. M. Adamowicz, PWSZ w Białej Podlaskiej, Biała Podlaska.

2. Bratnicki M., 2002, Przedsiębiorczość i przedsiębiorcy współczesnych organizacji, Wyd. Akademii Ekonomicznej w Katowicach, Katowice

3. Burchard-Dziubińska M., 2007, Ekologiczne determinanty rozwoju gospodarczego [w:] Ekonomika rozwoju, pod red. R. Piaseckiego, PWE, Warszawa.

4. Flejterski S., Wahl P.T., 2003, Ekonomia globalna, Difin, Warszawa.

5. Fukuyama F., 1997, Zaufanie. Kapitat spoteczny a droga do dobrobytu, Wyd. Naukowe PWN, Warszawa.

6. Janik W., 2006, Przedsiębiorczość jako czynnik rozwoju gospodarczego [w:] Teoria i praktyka ekonomii a konkurencyjność gospodarowania, red. E. Fejtag-Mika, Difin, Warszawa.

7. Kobylińska U., Glińska E, 2008, Wykorzystanie benchmarkingu w doskonaleniu systemów zarzqdzania placówkach samorzqdu terytorialnego [w:] Polska Wschodnia-zarzqdzanie rozwojem, pod red. B. Plawgo, WSAP, Białystok.

8. Kowalczewski W., Nazarka J., (red.), 2006, Instrumenty zarzq̨dzania wspótczesnym przedsiębiorstwem, Difin, Warszawa.

9. Kożuch B., 2001, Pojęcie i istota przedsiębiorczości [w:] Praktyczne problemy przedsiębiorczości, pod red. H. Wnorowskiego i A. Letkiewicza, Wyd. Uniwersytetu w Białymstoku, Białystok.

10. Linton R., 2000, Kulturowe podstawy osobowości, Wyd. Naukowe PWN, Warszawa.

11. M. Juchnowicz (red.), 2004, Kapitał ludzki a kształtowanie przedsiębiorczości, pod red., Poltext, Warszawa.

12. Pacholski M., Słaboń A., 1997, Słownik pojęć socjologicznych, Akademia Ekonomiczna w Krakowie, Kraków.

13. Quinn R.E., Faerman S.R., Thompson M.P., McGrath M.R., 2007, Profesjonalne zarzadzanie, PWE, Warszawa. 
14. Siek S., 1986, Struktura osobowości, Akademia Teologii Katolickiej, Warszawa

15. Sillamy N., 1998, Stownik psychologii, Wyd. Książnica, Katowice.

16. Strojny J., 2008a, Model zarzadzania strategicznego rozwojem lokalnym [w:] Polska Wschodniazarzqdzanie rozwojem, pod red. B. Plawgo, WSAP, Białystok.

17. Strojny J., 2008b, Wielowymiarowość zjawiska rozwoju małego i średniego przedsiębiorstwa [w:] Procesy zarzqdzania w zmieniajacej się gospodarce, red. T. Dyr, Z. Kwaśnik, Radomska Szkoła Wyższa, Radom 2008.

18. Strojny J., 2009, Zarzqdzanie przedsiębiorczościq w małej i średniej firmie, Oficyna Wydawnicza Politechniki Rzeszowskiej, Rzeszów.

19. Strojny J., Berezowska M., 2007, Przedsiębiorczość jako determinanta konkurencyjności organizacji zorientowanej projektowo [w:] Rola przedsiębiorczości w aktywizacji gospodarczej, red. Zioło Z., Tomasz R., ZPiGP Akademii Pedagogicznej w Krakowie, wydawnictwo Nowa Era, Warszawa-Kraków.

20. Targalski J., 1999, Przedsiębiorczość i rozwój firmy, Wyd. Akademii Ekonomicznej w Krakowie, Kraków.

21. Zaleśkiewicz T., 2004, Przedsiębiorczość i podejmowanie ryzyka [w:] Psychologia ekonomiczna, red. Tyszka T., Gdańskie Wydawnictwo Psychologiczne, Gdańsk.

\section{The Analysis of the Podkarpackie Voivodeship Entrepreneurial}

The article is concerned with one of the fundamental aspects of economic systems development in European integration and globalization contexts. It deals with the development of entrepreneurial potential in the Podkarpackie region. To explain the course of this process the author uses a model of entrepreneurial analysis that includes four levels: individual entrepreneurship, community entrepreneurship, organizational entrepreneurship and economy entrepreneurship. In the description of all these levels a measurement methodology is suggested. It is also important that the evaluation of entrepreneurial potential takes place on the mobile capital market. Territories (countries, regions, etc.), that offer better opportunities to develop have a greater chance of attracting mobile capital. Consequently, they can accelerate the development processes. Of course, administrative units that do not achieve economic and social progress do not attract external capital, and they cannot come out from stagnation despite the equalization mechanism both at domestic and European Union level.

On the base of this consideration the author analyzes the situation in the Podkarpackie voivodship in the terms of development opportunities in both the context of global and European integration. He attempts to specify the development potential in the area of entrepreneurial growth by using his proposal of models. To achieve this goal he uses statistical data and the results of a questionnaire that he himself conducted. Clearly, the article is not a complete diagnosis of the situation in the region as this would require a far more comprehensive publication and more in-depth research. This means that the rate of potential growth in the article are not comprehensive, and they may demand supplementation. Nevertheless, they can be used to formulate some useful conclusions and judge the situation accordingly. 